\title{
Antifungal Cream Preparation of Galangal rhizome Extract (Alpinia galanga L.)
}

\author{
Rety Setyawaty, Feriadi, Dewanto \\ Pharmacy Academy of Kusuma Husada, Purwokerto \\ Corresponding author: Rety Setyawaty : Email: rety.setyawaty@gmail.com
}

\begin{abstract}
Cream is a semi-solid emulsion dosage form of both water-in-oil (W/0) or oil in water $(\mathrm{O} / \mathrm{W})$ type containing one or more dissolved or dispersed ingredients in the corresponding base material (containing no less than $60 \%$ water). Cream is usually used as emollient or containing active pharmaceutical ingredients on the skin (Ansel, 2008). The advantage of cream are the application practicallity, water washeability, and the easiness to spread evenly. In this research, we formulated cream containing rhizome Galangal rhizome. According to Darmono (2008), Galangal rhizome has various properties such as antifungal and antibacterial activities. Galangal rhizome contains 1-asetoksikhavikol asetat (ACA). ACA is an antifungal. ACA has good solubility in $70 \%$ ethanol. We maserated Galangal rhizome (Alpinia galangal L.) to extract ACA from the simplicia. As for the cream base, we use hidrophilic base containing emulgators stearic acid and triethanolamine, with glycerin as humectant. During the optimization, we chose three formulas, formula $1(10 \%$ stearic acid , $2 \%$ triethanolamin, $5 \%$ glycerin, and $0.01 \%$ vitamin E), formula 2 (15\% stearic acid , $3 \%$ triethanolamin, $10 \%$ glycerin, and $0.05 \%$ vitamin E), and formula 3 (20\% stearic acid, $4 \%$ triethanolamin, $7.5 \%$ glycerin, and $0.09 \%$ vitamin E). We used the bases to contain $10 \%$ of the extract. The results show that formula 1, formula 2, and formula 3 had typical smell of Galangal rhizome, brown color, and thick consistency. All formulas are homogenous. Formula 1 the best stability. We conclude that Galangal rhizome (Alpinia galanga L.) can be formulated in cream form with our formula 1 had the best stability among others.
\end{abstract}

Keyword: cream formulation, antifungi, Galangal rhizome (Alpinia galanga L.)

\section{INTRODUCTION}

The climate in Indonesia supports the incidence of various tropical diseases, particularly skin infections caused by microbes, especially fungi. Skin infections caused by fungi is a difficult problem to overcome, because fungi survive more easily in the environment that is less favorable than other microscopic substances (Fatrotin, 2010). One of these diseases is dermatophytosis, caused by the infection of Trichophyton, Microsporum and Epidermophyton. This fungi infect the surface of human or animal bodies such as the skin, nails, hair, horns and feathers (Darmono, 2008).

The use of herbs as an alternative medicine tends to increase along with the expensive of several types of synthetic compounds. This is due to the growing awareness of the community to return to nature (Fitriati, 2007). One of medicinal plants used as a cure for skin diseases caused by fungi is Galangal Rhizome (Alpinia galanga L.). Galanga is a member of the Zingiberaceae family. Galangal rhizome is easy to obtain in Indonesia and works as a liniment for fungal skin disease (panu in bahasa) before modern medicine develops as it is now. Galangal rhizome has various properties including anti-fungal and antibacterial activities. Yuharmen et al., 2002 showed microbial growth inhibition activity by essential oils and methanol fraction of Galangal rhizomes in several species of bacteria and fungi. Suaib et al., 
2016 stated that the overall inhibitory effect of Galangal rhizome extract on the highest growth of 0 . theobrema fungi is at a concentration of $0.75 \%$ where the overall treatment showed a significant difference that had been tested at each concentration. The inhibitory effect of Galangal extract on the growth of fungus 0 . theobremae during observation at $0.25 \%$ was $20.47 \%$, at $0.50 \%$ was $27.10 \%$, and at $0.75 \%$ was $38.77 \%$.

Cream is a semi-solid emulsion dosage form of both water-in-oil (W/O) or oil in water $(\mathrm{O} / \mathrm{W})$ type containing one or more dissolved or dispersed ingredients in the corresponding base material (containing no less than $60 \%$ water). Cream is usually used as emollient or containing active pharmaceutical ingredients on the skin (Ansel, 2008). The advantage of cream are the application practicallity, water washeability, and the easiness to spread evenly. The concentration of Galangal rhizome extract in the cream was $10 \%$. This concentration was chosen based on the concentration range of Galangal rhizome extract which effectively inhibited the growth of M. Canis and T. Mentagrophytes. Hezmela (2006) conducted a study to determine the optimal range of extract concentrations to inhibit the growth of the two test fungi. Based on the research conducted, it is known that the concentration range of extract to inhibit the growth of $M$. Canis is $0.3 \%-5 \%$, while for $T$. Mentagrophytes is $0.5 \%-10 \%$.

The cream contained stearic acid as a base of cream and emulsifier in the oil phase, triethanolamine as emulsifier in water phase, glycerine as humectant, $\alpha$ tocopherol as antioxidant, methylparaben as preservative in oil phase, and propyl paraben as preservative in water phase. The formula design is formula 1 (10\% stearic acid , 2\% triethanolamin, 5\% glycerin, and $0.01 \%$ vitamin E), formula 2 (15\% stearic acid , 3\% triethanolamin, $10 \%$ glycerin, and $0.05 \%$ vitamin E), and formula $3(20 \%$ stearic acid, 4\% triethanolamin, $7.5 \%$ glycerin, and $0.09 \%$ vitamin E).. Galangal rhizome extract in the cream was $10 \%$. The formulation cream can be seen in Table 1 .

O/W cream was formulated by combining stearic acid and triethanolamine (TEA). TEA was chosen as an emulgator because TEA will form an oil emulsion in water which is very stable when combined with free fatty acids. The most suitable fatty acids to be combined with TEA are stearic acid because stearic acid does not experience discoloration like oleic acid (Cosmetic Ingredient Review Expert Panel, 1995). Stearic acid reacts with TEA in situ to produce a salt, triethanolamine stearate which functions as an emulgator for oil-inwater type emulsions (Aulton, 2002). The salt formed is the result of a stoichiometric reaction. Each component reacts with an appropriate comparison. 2-4\% of TEA and $5-15 \%$ stearic acid generally used depends on the amount of oil to be emulsified (Jenkins et al., 1957). Stearic acid in Allen (2009) was used at concentrations of 1$20 \%$. Stearic acid is neutralized using a flavoring agent or triethanolamin to avoid skin irritation because of the compounds. This research used $10-20 \%$ stearic acid and 2-4\% TEA.

Glycerin as humectants with the consideration that glycerin will resist evaporation of water in the cream preparation and in the skin serves as a moisturizer (Hendradi et al, 2013). The use of glycerin is common between $10-20 \%$ (Tranggono and Latifah, 2007).. This research use 5-10\% glycerine as humectant.

Vitamin E is a fat-soluble antioxidant that protects the skin from oxidative stress, one of which is photoaging. Photoaging is premature aging due to the continuous production of oxygen radicals in the skin from UV light. Many studies documented that vitamin $\mathrm{E}$ has major antioxidant and photoprotection activities efficient enough to reduce the frequency and severity of pathological events in the skin (Nachbar \& Korting, 1995). The use of $0.5 \%$ vitamin E in cream preparations only enough to penetrate $4.3 \%$ of the skin, so it is 
recommended to use at least $1 \%$ of vitamin $E$ in order to penetrate into the skin and produce the expected therapeutic effect. According to a survey conducted by the Personal Care Products Council in 2013, the maximum concentration of vitamin $\mathrm{E}$ used in products with dermal / skin contact is $5.4 \%$. Most of the $\alpha$-tocopherols used in topical cosmetic products had $5 \%$ or less (Hasibuan et al., 2014). This research use vitamin $\mathrm{E}$ in the range of $0.01-0.09 \%$, expected to be enough to penetrate the skin.

\section{METHODS}

\section{Galangal Rhizome (Alpinia galanga L.) Extraction}

Cutting tool (knife), grinder, maseration container, rotary evaporator, extract container, and oven. Cream production, analytical balance, porcelain cup, glass watch, paper parchment, spoon horn, glass beaker $250 \mathrm{ml}$, glass beaker $1000 \mathrm{ml}$, small glass beaker, $100 \mathrm{ml}$ measuring cup, $10 \mathrm{ml}$ measuring cup, drops, waterbath, stirrer, spindle, and mortar.

\section{Materials}

$100 \mathrm{~g}$ of simplicia Galangal rhizome, $70 \%$ of ethanol, aluminum foil, and filter paper. While the ingredients used in the preparation of the cream are the ethanol extract of Galangal rhizome, stearic acid, triethanolamine (TEA), glycerine, $\alpha$ tocopherol, methyl paraben, propyl paraben and aquadest.

Samples of Galangal rhizome (Alpinia galanga L.) were freshly taken in Pepedan village, Karangmoncol district, Purbalingga regency. Samples were washed thoroughly in running water. Clean samples were sorted wet and aerated to reduce moisture content. Samples were chopped and dried by aerated in a place that is not exposed to direct sunlight. After drying, it was drysorted and milled. Simplicia of Galangal rhizome was weighed $100 \mathrm{~g}$ and put into a container. Two liters of 70\% ethanol (until the simplicia is submerged) were added to the jar containing the sample. The container was then closed tightly. The maceration process was for 3 days at room temperature, protected from light, and occasionally stirred. Filtrate was collected and evaporated using waterbath to obtain thick extract. Evaporation was stopped at $10 \%$ yield (MOH, 2010).

\section{Cream Production}

Before used a raw material for cream, no characterization of Galangal rhizome was carried out. Reference to the anti fungi possessed by Galangal rhizome is taken from the research of (Yuharmen et al., 2002) and (Suaib et al., 2016). Suaib et al., 2016 states that the overall inhibitory effect of Galangal rhizome extract on the highest growth of 0 . theobrema fungi is at a concentration of $0.75 \%$ where the overall treatment showed a significant difference. The inhibitory effect of Galangal extract on the growth of fungus 0 . theobremae during observation at a $0.25 \%$ was $20.47 \%, 0.50 \%$ was $27.10 \%$, and $0.75 \%$ was $38.77 \%$. It is expected that the levels of $10 \%$ Galangal rhizome extract can stop fungal activity better than those obtained in Suaib's (2016) study. In addition, the concentration of Galangal rhizome of $10 \%$ was chosen based on the concentration range of galangal extract which effectively inhibit the growth of M. Canis and T. Mentagrophytes. Hezmela (2006) conducted a study to determine the optimal range of extract concentrations to inhibit the growth of the two test fungi. Based on the research conducted, it is known that the concentration range of extract to inhibit the growth of $M$. Canis was $0.3 \%$ - 5\%, while for T. Mentagrophytes was $0.5 \%-10 \%$. Formula 1, 2 and 3 (Table I). The choice of formula was based on the function of each ingredient used and the expected cream product. The amount ingredients were used was decided by considering the combination.

All materials were weighed according to the results of the calculations contained 
Table I. Cream Formulas

\begin{tabular}{lccc}
\hline \multirow{2}{*}{ Components } & \multicolumn{3}{c}{ Concentrations (w/w) } \\
\cline { 2 - 4 } & Formulation 1 & Formulation 2 & Formulation 3 \\
\hline Galangal rhizome extract & $10 \%$ & $10 \%$ & $10 \%$ \\
Stearic acid & $10 \%$ & $15 \%$ & $20 \%$ \\
?-tocopherol (Vitamin E) & $0.01 \%$ & $0.05 \%$ & $0.09 \%$ \\
Methyl paraben & $0.15 \%$ & $0.15 \%$ & $0.15 \%$ \\
Triethanolamine (TEA) & $2 \%$ & $3 \%$ & $4 \%$ \\
Glycerine & $5 \%$ & $10 \%$ & $7.5 \%$ \\
Propyl paraben & $0.03 \%$ & $0.03 \%$ & $0.03 \%$ \\
Aquadest ad & $30 \mathrm{~g}$ & $30 \mathrm{~g}$ & $30 \mathrm{~g}$ \\
\hline
\end{tabular}

in (Table I). Separate the materials to be dissolved in the oil phase and water phase. Oil phase was made by combining between stearic acid, $\alpha$-tocopherol, and methyl paraben successively above the waterbath while stirring until homogeneous. Temperature was maintained at $50^{\circ} \mathrm{C}$. For the water phase, triethanolamine, glycerin, and propylparaben were dissolved above the waterbath while continuously stirring. The temperature was maintained at $70^{\circ} \mathrm{C}$. The water phase was put into the heated mortar. The oil phase was gradually loaded into the water phase while crushed to form a cream base, then water was added. Galangal rhizome extracts were fed into the cream base in bits. The mixture was stirred until homogeneous (Sulastri et al., 2016).

\section{Cream Physical Stability Testing}

Organoleptic Testing

Organoleptic testing was including the check for the color, consistency, and smell of cream preparations.

Homogeneity Testing

Samples of cream were taken as much as $0.1 \mathrm{~g}$ then smeared on a transparent glass. Observation was the made in the event of phase separation.

\section{$\mathrm{pH}$ Testing}

$\mathrm{pH}$ measurements were carried out using a universal $\mathrm{pH}$ indicator.

\section{RESULTS AND DISCUSSION Yield of Thick Extract}

Evaporation process yielded 26.17 grams or $26.17 \%$ extract. When evaporation process in waterbath, ethanol will evaporate first than water. This means that in the yield of $26.17 \%$ was still containing water. The amount of rendement in the extract according to Afif (2006) was caused by factors of extraction method, amount of solvent, extraction time, powder size and temperature. Water levels that exceed the requirements allow fungal growth (MOH, 1986). Figure 1 shows thick extract of Galangal rhizome (Alpinia galangal L.).

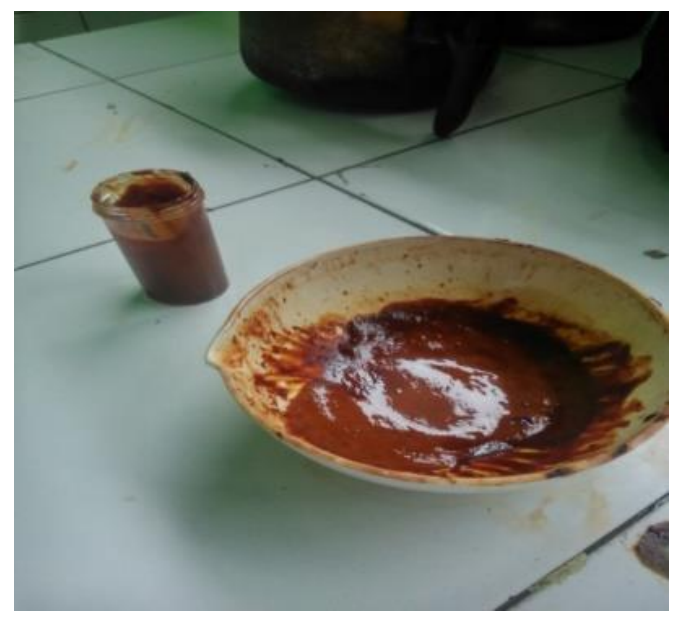

Figure 1. Thick extract of Galangal rhizome (Alpinia galangal L.) 
Table II. Organoleptic Test

\begin{tabular}{ccc}
\hline Formula & Test & Physical apparence \\
\hline \multirow{2}{*}{1} & Smell & Specific \\
& Color & Brown \\
& Consistency & Soft and tend to be thick \\
2 & Smell & Specific \\
& Color & Brown \\
& Consistency & Thick \\
3 & Smell & Specific \\
& Color & Brown \\
& Consistency & Very thick \\
\hline
\end{tabular}

\section{Organoleptic Testing}

In the preparations of the first formula, the cream were soft and tend to thick. In the second formula, it was thick, and in the third formula was very thick. This was because the concentration of the base and emulgator that played a role in the formation of cream consistency in each formula (Table II).

The brown color of cream is obtained from the color of Galangal rhizome extract. This was different with the yellowish white color obtained in the research of (Rahmalia et al., 2010).

The typical smell of cream was resulted from Galangal rhizome smell. In O/W type of cream, the presence of stearic acid can cause the cream to be softer that its viscosity is lower. Cream base types that have high viscosity will cause the diffusion coefficient of a drug in the base to be low, so the release of the drug from the base will be small (Lachman et al., 1989). Stearic acid in Allen (2005) is used at concentrations of 1$20 \%$. Stearic acid was neutralized using a flavoring agent or triethanolamin to not to irritate the skin so that it can be used in cream preparations. Triethanolamine is a mixture comprising mainly 2-2-2nitrilotreietanol $\left(\mathrm{C}_{2} \mathrm{H}_{4} \mathrm{OH}\right) 3 \mathrm{~N}$, together with 2,2-iminoloisetanol and a small amount of 2-aminoethanol (Anonym, 1995). Triethanolamine is usually combined with fatty acidic substances to form water-soluble soaps (Triethanolamine stearate) (Voigt, 1984) used as a regulator of $\mathrm{pH}$, surfactant, foam and cleanser (Anonym, 1995).

Cream viscosity is influenced by the presence of fatty acids contained in the cream, namely stearic acid. The more the amount of fatty acids used, the resulting cream will also be harder. Triethanolamine may also be a water-phase emulsifier which is thinner than the oil phase (stearic acid) so the consistency of the resulting cream was then decreased. The use of stearic acid as an emulsifier in a topical preparation will form a thick base and its viscosity is determined by the amount of triethanolamine used (Allen, 2009). Allen (2009) also mentioned that the formulation of cream preparations with the use of staric acid emulsifier and TEA can affect the viscosity and $\mathrm{pH}$ of the preparation.

\section{Homogeneity Testing}

Homogeneity test was done by observing the color of the preparation visually and see if there were parts that were not mixed well in the cream. The cream can be claimed to be homogeneous if there is color homogeneity and no particles are found in the cream (Ida \& Noer, 2012). Homogeneity affects the effectiveness of therapy because it is associated with the same drug levels in each application. Cream is a preparation in which the application is applied to the treatment site, so that each part of the active ingredient must have 


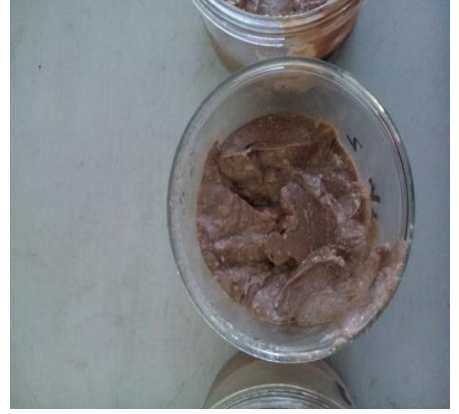

Formula 1

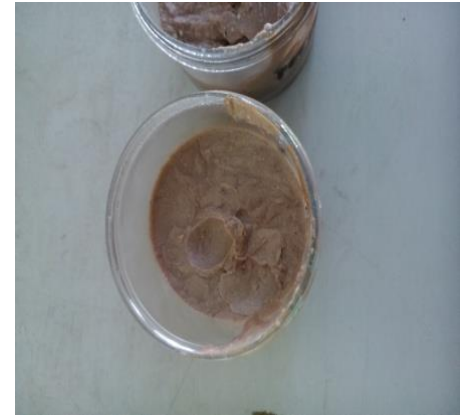

Formula 2

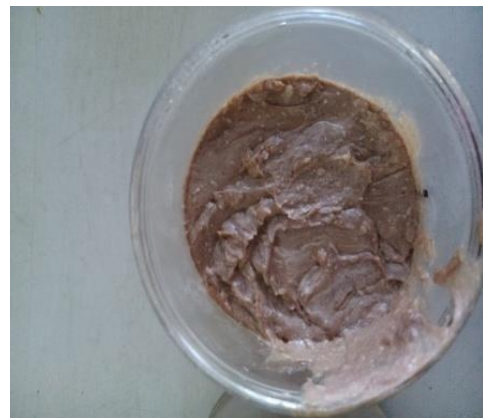

Formula 3

Figure 3. Stability of cream

equal opportunity to occupy the therapeutic site. This condition can be achieved when the cream is homogeneous. All formulas were homogenous.

The homogeneity of a cream preparation is influenced by several factors such as temperature accuracy for melting, and stirring. If the temperature used for the fusion of an ingredient does not match the melting point of the material, then the material will not dissolve and mix with other ingredients. The final result will be fine particles in the glass as a test indicator of its homogeneity. In addition, the cream homogeneity is also influenced by the Galangal rhizome extract which is not evenly mixed and homogeneous during mixing. Figure 2 shows the homogeneinity test of cream.

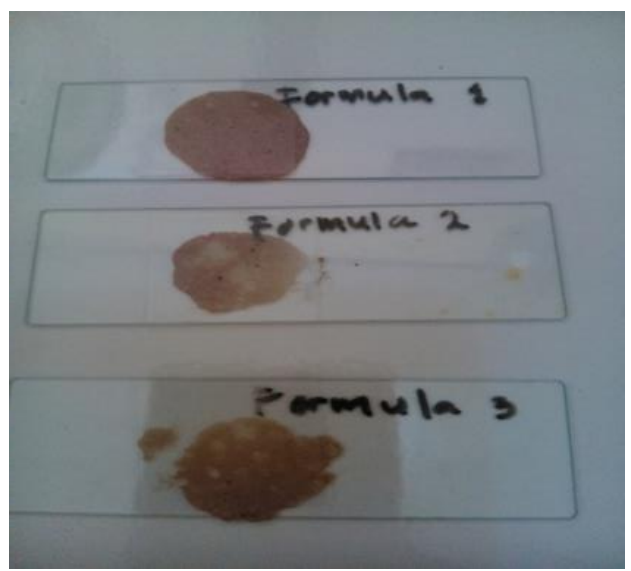

Figure 2. Homogeinity test

\section{pH Measurement}

The $\mathrm{pH}$ measurement needs to be done to determine the safety of cream preparations when used so that they do not irritate the skin (Juwita et al., 2013). If the preparation is too acidic it will irritate the skin, while too basic cream will cause the skin to become dry during use (Ainaro et al., 2015). Ph testing showed that the $\mathrm{pH}$ test results for all formulas of cream preparations were 6 . This result was as expected, where both cream preparations have acidity that matches the normal $\mathrm{pH}$ range of the skin, which is 4.5 to 6.5 (Naibaho, 2013).

\section{Stability Testing}

Stability testing was performed to ensures the identity, strength, quality, and purity of the product to be persist during the expected storage time period.

Formula 1 is more stable than formula 2 and formula 3 because because the less use of emulgator stearic acid. Formula 2 contained 15\% stearic acid and formula 3 contained $20 \%$ stearic acid. Figure 3 shows the stability of cream.

According to (Rowe et al., 2009), combination of stearic acid and triethanolamine will form a salt of triethanolamine stearate which is anionic and produces fine grains thus stabilize the type of oil emulsion in water or vanishing cream. 


\section{CONCLUSION}

According to out study, it can be concluded that, galangal rhizome (Alpinia galanga $\mathrm{L}$.) can be can be formulated into cream preparation, and the formula of cream using stearic acid of $10 \%$ and triethanolamine of $2 \%$ as emulgator (Formula 1) has more stable than Formula 2 (stearic acid of $15 \%$ and triethanolamine of $3 \%$ ) and formula 3 (stearic acid of $20 \%$ and triethanolamine of $4 \%$ ) for $10 \%$ of Galangal rhizome extract (Alpinia galanga L.).

\section{DAFTAR PUSTAKA}

Afif KH. 2006. Peningkatan kadar kurkumin ekstrak etanol temulawak dengan metode ekstraksi cair-cair. Skripsi. Bogor (ID): Institut Pertanian Bogor.

Ainaro, E.P., Amilia, G., Sani, E.P. 2015. Formulasi Sediaan Masker Gel Pell-Off Mengandung Lender Bekicot (Achatina Fulica Bowdich) Sebagai Pelembab Kulit. Fakultas MIPA Unisba, ISSN 2460-6472.

Akhtar, Naveed, Arshad Mehmood, Barkat Ali Khan, Tariq Mahmood, Haji Muhammad Shoaib Khan and Tariq Saeed. 2011. Exploring cucumber extract for skin rejuvenation. African Journal of Biotechnology, Vol. 10 (7), pp. 1206-1216.

Allen, L. V. 2009. Handbook of Pharmaceutical Excipients,

Pharmaceutical Press and American Pharmacists Association, $6^{\text {th }}$, USA, pp. 697-699,

Ansel, H. C. 2008. Pengantar Bentuk Sediaan Farmasi ed IV, Alih bahasa Ibrahim, F. Jakarta : UI Press.

Anonym. 1995. Farmakope Indonesia. Edisi IV. Jakarta: Departemen Kesehatan Republik Indonesia.

Armstrong, N.A. 2006. Gelatin, Magnesium stearat, Asam sitrat, Laktosa. Handbook of Pharmaceutical Excipients. American Pharmaceutical Association, Washington DC, pp. 185187, 295-298, 430-433, 385-388.
Aulton, M.E. 2002. Pharmaceutics: the science of dosage form design. E-Book. Cosmetic Ingredient Review Expert Panel. 1995. Final Report on the Safety Assessment of TEA Stearate. Journal of the Americnn College of Toxicology, 14(3):24\&248. Raven Press Ltd, New York.

Darmono.2008. Jurnal Ilmu Kefarmasian Indonesia. Departemen Kesehatan Republik Indonesia, pp. 57-62.

Fatrotin. 2010. Pengantar Formulasi Tumbuhan Sebagai Pengobatan Infeksi Jamur.

Fitriati. 2007. Aplikasi Ekstrak Lengkuas $S$ (Alpinia galanga L. Swartz), Jakarta.

Hasibuan, Ririn, K., Fahrurroji, A., and Eka Kartika Untari. 2014. Formulasi dan Uji Sifat Fisikokimia Sediaan Losio dengan berbagai Variasi Konsentrasi Vitamin E. Skripsi. Program Studi Farmasi, Fakultas Kedokteran, Universitas Tanjungpura, Pontianak.

Hendradi E., Chasanah U., Indriani T., and Fidela Fionnayuristy. 2013. Pengaruh Gliserin dan Propilenglikol terhadap Karakteristik Fisik, Kimia dan SPF Sediaan Krim Tipe 0/W Ekstrak Biji Kakao (Theobroma cacao L.). PharmaScientia, Vol.2, No.1, Juli.

Hezmela, R. 2006. Daya Antijamur Ekstrak Lengkuas Merah (Alpinia purpurata K. Schum) dalam Sediaan Shampo. Skripsi. TIN. FATETA. IPB. Bogor.

Ida, N., and Noer, S.F. 2012. Uji Stabilitas Fisik Gel Ekstrak Lidah Buaya (Aloe vera I.). Majalah Farmasi dan Farmakologi, 16 (2): 79-84.

Juwita, Anisa, P., Yamlean, P.V.Y., and Hosea Jaya Edy. 2013. Formulasi Krim Ekstrak Etanol Daun Lamun (Syringodium isoetifolium). PHARMACON Jurnal Ilmiah Farmasi UNSRAT, Vo.2 No.02. Mei. ISSN 2302 2493.

Lachman L, Martin MR dan Gilbert SB. 1989. Pharmaceutical Dosage Forms: Disperse System. Volume 1.Edisi ke2.Marccel Dekker. New York, pp. 1-47. 
MOH. 1986. Sediaan Galenika. Jakarta, Departemen Kesehatan Republik Indonesia.

MOH. 2010. Farmakope Herbal Indonesia. Jakarta: Departemen Kesehatan Republik Indonesia.

Naibaho, Olivia H. Paulina V.Y. Yamlean, Weny Wiyono. 2013. Pengaruh Basis Salep Terhadap Formulasi Sediaan Salep Ekstrak Daun Kemangi (Ocimun Sanctum L.) Pada Kulit Punggung Kelinci Yang Dibuat Infeksi Staphyloccocus Aureus. Jurnal Ilmiah Farmasi - UNSRAT, Vol 2 No 02. ISSN 2302-2493.

Pertiwi, E.D. 2015. Formulasi Sediaan Pelembab Perasan Buah Jeruk Bali (Citrus maxima) dalam Bentuk Sediaan Krim. Skripsi. Fakultas Farmasi, Universitas Katolik Widya Mandala Surabaya.

Rahmalia, R., Sudirman, I., and Dwi Hartanti. 2010. Aktivitas Anti Jamur Krim Mintak Atsiri Rimpang Lengkuas (Alpinia galangal L.) terhadap Candida albicans. Pharmacy, Vo.07 No. 02, Agustus.

Rowe, R. C., Sheskey, P. J. and Quinn, M.E. 2009. Handbook of Pharmaceutical Excipients, Sixth Edition, Pharmaceutical Press, Italia, pp. 517519.
Suaib, I, Lakani, I and Johanis P. 2016. Efektifitas Ekstrak Rimpang Lengkuas dalam Menghambat Aktifitas Cendawan (Oncobasidium theobremae) secara In-vitro. E-J. Agrotekbis 4(5): 506-511. ISSN: 23383011.

Sulastri, E., Mappiratu, and Annisa Kartika S. 2016. Uji Aktivitas Antibakteri Krim Asam Laurat terhadap Staphylococcus aureus ATCC 25923 dan Pseudomonas aeruginosa ATCC 27853. GALENIKA Journal of Pharmacy, Vol.2(2): 59-67, October.

Swastika, A. Mufrod \& Puwanto. 2013. Aktivitas Antioksidan Krim Ekstak Sari Tomat (Solanum lycopersicum L.). Trad Med Journal, 18(3), 132-140.

Tranggono, I.R. \& Latifah, F. 2007. Buku Pegangan Ilmu Pengetahuan Kosmetik. PT. Gramedia Pustaka Utama. Jakarta.

Yuharmen, Yum Eryanti, Nurbalatif. 2002. Uji Aktivitas Antimikroba Minyak Atsiri dan Ekstrak Metanol Lengkuas (Alpinia galanga). http://www.unri.ac.id/jurnal/ju rnal_natur/vol4(2)/yuharmen.p $d f$. Diakses pada 21 November 2009.

Voigt, R. 1984. Buku Ajar Teknologi Farmasi, Edisi V, diterjemahkan oleh Soewandhi, S. N., Edisi 5, UGM Press, Yogyakarta, pp. 312-338. 